\title{
KEBIJAKAN FISKAL DALAM PANDEMI COVID-19: DAMPAK DAN TANTANGAN PENERIMAAN PAJAK DI KPP WAJIB PAJAK BESAR DUA
}

\author{
Riyanto ${ }^{a}$, Nyoman Asri Hapsari Pande Mudara ${ }^{b}$ \\ a KPP Wajib Pajak Besar Dua, Jakarta Selatan. Email: riyanto.san@gmail.com \\ b Kanwil DJP Wajib Pajak Besar, Jakarta Selatan. Email: asrihapsaripm@gmail.com
}

\begin{abstract}
COVID-19 that has hit the world has an impact on the Indonesian economy. Tax revenue at Large Tax Office Two is also affected by the COVID-19 pandemic caused by delays in international and domestic trade. This study aims to determine the magnitude of the impact of the COVID-79 pandemic on tax revenues and the need for fiscal incentives in the context of economic recovery. The method used in this research is a descriptive quantitative method using a secondary data analysis approach. Based on the research results, the impact of the COVID-19 pandemic has caused a significant decrease in tax revenue. Fiscal incentives in the form of income tax Borne by Government need to be expanded and the criteria made easier so that employees get additional economic capacity that employees can use to encourage domestic economic rotation.
\end{abstract}

Keywords: COVID-19 pandemic, tax revenue, fiscal policy

\section{ABSTRAK}

COVID-19 yang melanda dunia memberikan dampak pada perekonomian Indonesia. Penerimaan pajak di Kantor Pelayanan Pajak Wajib Pajak Besar Dua juga terdampak atas pandemi COVID-19 yang disebabkan tersendatnya perdagangan internasional dan perdagangan barang dan jasa dalam negeri. Penelitian ini bertujuan mengetahui besaran dampaknya pandemi COVID-19 bagi penerimaan pajak, serta perlunya insentif fiskal dalam rangka pemulihan ekonomi. Metode yang digunakan dalam penelitian ini adalah metode kuantitatif deskriptif dengan menggunakan pendekatan analisis data sekunder. Berdasarkan hasil penelitian, dampak pandemi COVID-19 telah menyebabkan penurunan penerimaan pajak yang cukup signifikan. Insentif fiskal berupa Pajak Penghasilan pasal 21 ditanggung Pemerintah (DTP) perlu diperluas dan kriterianya dipermudah agar karyawan mendapatkan tambahan kemampuan ekonomis yang dapat digunakan karyawan untuk mendorong perputaran Kata kunci: pandemi COVID-19, penerimaan pajak, kebijakan fiskal 


\section{PENDAHULUAN}

Penyakit COVID-19 pertama kali terkonfirmasi dari Wuhan, Cina di akhir tahun 2019 dan dinyatakan sebagai pandemi oleh WHO. Penyakit tersebut telah menjangkiti lebih dari 134.957.021 manusia dan menyebabkan banyak kematian dengan jumlah 2.918.752 korban jiwa (World Health Organization, 2020). Selain mengakibatkan krisis kesehatan, pandemi ini telah menimbulkan krisis di bidang perekonomian di dunia. Organisation for Economic Cooperation and Development (OECD), memprediksi pertumbuhan ekonomi global sebesar 4,2\% pada 2020. Kontraksi ini tak lepas dari pandemi COVID-19 yang menghantam perekonomian global (CNBC Indonesia TV, 2020). Adapun di Indonesia, Badan Pusat Statistik menyatakan pertumbuhan ekonomi Indonesia di tahun 2020 adalah sebesar $-2.07 \%$ sebagai dampak dari pelemahan di berbagai sektor ekonomi karena pandemi COVID-19 (Pink, 2021). Selain menimbulkan dampak kematian yang tinggi dan terganggunya sektor pariwisata, pandemi COVID-19 juga menyebabkan ekspor impor barang terganggu sehingga transaksi perdagangan antar negara menjadi tersendat. Dampak selanjutnya adalah tingkat pertumbuhan perekonomian nasional yang menurun dan cenderung negatif. Dampak sistematik lainnya akan menyebabkan kenaikan pengangguran dan penurunan penerimaan negara dari pajak.

Pemerintah Indonesia perlu mengambil kebijakan yang komprehensif dan terarah di bidang fiskal dan moneter untuk menghadapi pandemi COVID-19. Beberapa kebijakan moneter dapat diambil, dalam hal ini Bank Indonesia memiliki inovasi dalam Quantitative Easing (QE) untuk mendukung sektor riil khususnya UMKM, mengawal pembukaan sektor-sektor ekonomi dengan tetap menerapkan protokol kesehatan, restrukturisasi kredit untuk mendorong pertumbuhan ekonomi, dan mendukung digital economy (Webinar Efektifitas Kebijakan Moneter Masa Pandemi COVID-19 Di Indonesia, 2020).

Sejak awal April 2020, beragam insentif fiskal telah diberikan pemerintah, sebagian termuat dalam PMK No. 28/PMK.03/2020 yang diterbitkan pada tanggal 6 April 2020. Dari segi subjek, ada tiga pihak yang diberi insentif, yaitu instansi pemerintah, rumah sakit rujukan, dan pihak lain yang ditunjuk oleh instansi pemerintah atau rumah sakit tadi untuk mendukung penanganan COVID-19 (Saptati, 2020).

PMK No. 28/PMK.03/2020 tersebut mengatur tentang Pemberian Fasilitas Pajak Terhadap Barang dan Jasa Yang Diperlukan Dalam Rangka Penanganan Pandemi Corona Virus Disease 2019, di mana terdapat fasilitas Pajak Pertambahan Nilai (PPN) tidak dipungut atas impor barang tertentu dalam rangka penanggulangan COVID-19. PMK tersebut kemudian diganti dengan PMK No. 143/PMK.03/2020 tanggal 01 Oktober 2020. Sebelumnya terdapat insentif fiskal yang lain yang diberikan pemerintah melalui Kementerian Keuangan pada tanggal 21 Maret 2020, yaitu PMK 
No. 23/PMK.03/2020 tentang Insentif Pajak Untuk Wajib Pajak Terdampak Wabah Virus Corona. Adapun PMK ini telah beberapa kali mengalami perubahan. Dampak insentif fiskal ini dirasakan oleh Kantor Pelayanan Pajak Wajib Pajak Besar Dua, selanjutnya disebut KPP Wajib Pajak Besar Dua, sebagai miniatur dari penerimaan pajak nasional karena merupakan kantor pelayanan pajak dengan target penerimaan terbesar di Indonesia.

\section{KERANGKA TEORI}

Dampak pandemi COVID-19 secara tidak langsung berpengaruh pada penurunan penerimaan pajak di KPP Wajib Pajak Besar Dua. Menteri Keuangan Sri Mulyani memprediksi turunnya pendapatan negara dari sisi penerimaan pajak sebesar 10 persen di tahun 2020 (Friana, 2020).

Pemerintah memberikan stimulus fiskal, berupa pemberian insentif pajak dalam skala besar untuk mendukung dunia usaha serta orang pribadi yang terdampak karena adanya pelambatan ekonomi. Blanchard sebagaimana dikutip dalam Darussalam (2020) menyatakan kebijakan fiskal pemerintah di saat pandemi COVID-19 berfokus pada tiga aspek. Pertama, fokus pada upaya menanggulangi aspek kesehatan masyarakat. Kedua, instrumen fiskal untuk mendorong permintaan total (aggregate demand). Ketiga, kebijakan fiskal haruslah berperan sebagai aid atau membantu pihak-pihak yang terdampak pelemahan ekonomi. Fokus yang terakhir ini berupa penyelamatan sektor ekonomi sehingga dampaknya mampu mendorong roda perekonomian.

Pendekatan

Keynisian mengasumsikan adanya price rigidity dan access capacity sehingga output ditentukan oleh permintaan agregat (demand driven). Keyness menyatakan bahwa dalam kondisi resesi, perekonomian yang berbasis mekanisme pasar tidak akan mampu pulih tanpa intervensi dari pemerintah (Feranika \& Haryati, 2020).

Dalam rangka penanggulangan dampak COVID-19, pemerintah perlu mengambil kebijakan yang akan mampu memulihkan perekonomian melalui stimulus fiskal. Namun di sisi lain, pemberian stimulus fiskal akan berdampak pada penerimaan perpajakan.

\section{METODOLOGI PENELITIAN}

Metode yang dipergunakan dalam penelitian ini adalah metode kuantitatif deskriptif, yaitu menggunakan pendekatan yang dikenal dengan analisa data sekunder (Sugiyono, 2013). Analisa data sekunder yaitu suatu metodologi penelitian yang menggunakan data sekunder sebagai sumber data utama (Carpendale et al., 2017). Pemanfaatan data sekunder yang dimaksudkan adalah dengan memakai suatu teknik uji statistik yang sesuai untuk memperoleh informasi yang dibutuhkan dari data-data yang dikeluarkan oleh suatu instansi yang berkompeten untuk kemudian diolah secara sistematis dan objektif.

Hasil analisis data dalam penelitian kuantitatif biasanya disajikan dengan piktogram dan grafik lingkaran, grafik batang, atau garis dan tabel distribusi frekuensi (McNabb, 2017). Pembahasan 
terhadap analisis penelitian akan dijelaskan lebih mendalam dan detail guna menghasilkan kesimpulan yang berisikan jawaban singkat terhadap rumusan masalah berdasarkan data yang telah dikumpulkan. Penelitian ini merupakan penelitian deskriptif yang bertujuan untuk mencatat, mendeskripsikan, menginterpretasikan, dan menganalisis yang dilakukan pada situasi yang saat ini terjadi. Penelitian ini bertujuan untuk mendapatkan informasi-informasi tentang kondisi sekarang dan kemudian menganalisis keterkaitan antara variabel-variabel yang ada (Moen dan Middelthon, 2015).

Adapun data sekunder yang dipergunakan dalam penelitian ini adalah data terkait penerimaan pajak dari KPP Wajib Pajak Besar Dua yang telah diolah oleh penulis. Bogdan menjelaskan bahwa data analisis adalah suatu langkah menyusun dan mencari secara sistematis data yang diperoleh dari catatan lapangan dan bahan-bahan lain, sehingga akan mudah dimengerti, dan hasil temuan yang di dapat bisa diinformasikan kepada masyarakat yang membutuhkan (Minakshi, 2017).

\section{HASIL DAN PEMBAHASAN}

Data COVID-19 Indonesia menurut Komite Penanganan COVID-19 dan Pemulihan Ekonomi Nasional, pasien terkonfirmasi positif yang tercatat sejak kasus pertama mencapai 1.562 .868 kasus, kasus positif dengan kesembuhan 1.409.288, dan pasien COVID-19 meninggal sejumlah 42.433 (Komite Penanganan COVID-19 Dan Pemulihan Ekonomi Nasional, n.d.).

\subsection{Penurunan Aktivitas Impor Barang}

Dampak pandemi di Cina, selaku negara yang pertama kali terdampak virus, telah menyebabkan terganggunya pasokan barang di Indonesia dari Cina. Hal ini dikarenakan impor barang terbanyak Indonesia adalah dari Cina, sebagaimana data dari kemendag.go.id yang menyatakan bahwa tiga negara pemasok barang impor nonmigas terbesar selama tahun 2020 ditempati oleh Tiongkok dengan nilai US\$ 39,35 miliar (30,91\%), Jepang dengan nilai US $\$ 10,62$ miliar (8,35\%), dan Singapura dengan nilai US\$ 8,1 miliar (6,38\%).

Penurunan jumlah pasokan barang untuk bahan baku yang akan diolah lebih lanjut akan mengganggu proses produksi dari industri manufaktur dalam negeri. Demikian juga penurunan pasokan barang yang siap dijual dalam negeri akan membuat transaksi jual beli barang menjadi berkurang. Dampak dari kedua hal tersebut, secara fiskal, akan mengurangi pemasukan negara dari sektor perpajakan.

Impor terbesar pada tahun 2019 yang diperoleh dari portal statistik perdagangan adalah raw material support sebesar 126.355,36 juta USD atau sebesar 73,77\% dari keseluruhan impor. Raw material support juga merupakan impor terbesar pada tahun 2020 dengan nilai 103.209,94 juta USD atau sebesar $72,9 \%$ dari keseluruhan impor (Kementerian Perdagangan, 2021). Adapun total impor barang selama 2019 dan 2020 ditampilkan dengan tabel di bawah ini. 
Tabel 1 Impor Indonesia (Jutaan USD)

Sumber: Kementerian Perdagangan

\begin{tabular}{|l|r|r|}
\hline \multicolumn{1}{|c|}{ MASA } & TAHUN 2019 & TAHUN 2020 \\
\hline JANUARI & $15.005,19$ & $14.268,72$ \\
\hline FEBRUARI & $12.465,07$ & $11.548,10$ \\
\hline MARET & $13.746,62$ & $13.352,18$ \\
\hline APRIL & $15.399,19$ & $12.535,23$ \\
\hline MEI & $14.606,66$ & $8.438,63$ \\
\hline JUNI & $11.495,39$ & $10.760,32$ \\
\hline JULI & $15.518,48$ & $10.464,30$ \\
\hline AGUSTUS & $14.169,35$ & $10.742,41$ \\
\hline SEPTEMBER & $14.263,45$ & $11.570,10$ \\
\hline OKTOBER & $14.759,08$ & $10.786,02$ \\
\hline NOVEMBER & $15.340,48$ & $12.664,41$ \\
\hline DESEMBER & $14.506,78$ & $14.438,38$ \\
\hline TOTAL & $171.275,74$ & $141.568,80$ \\
\hline
\end{tabular}

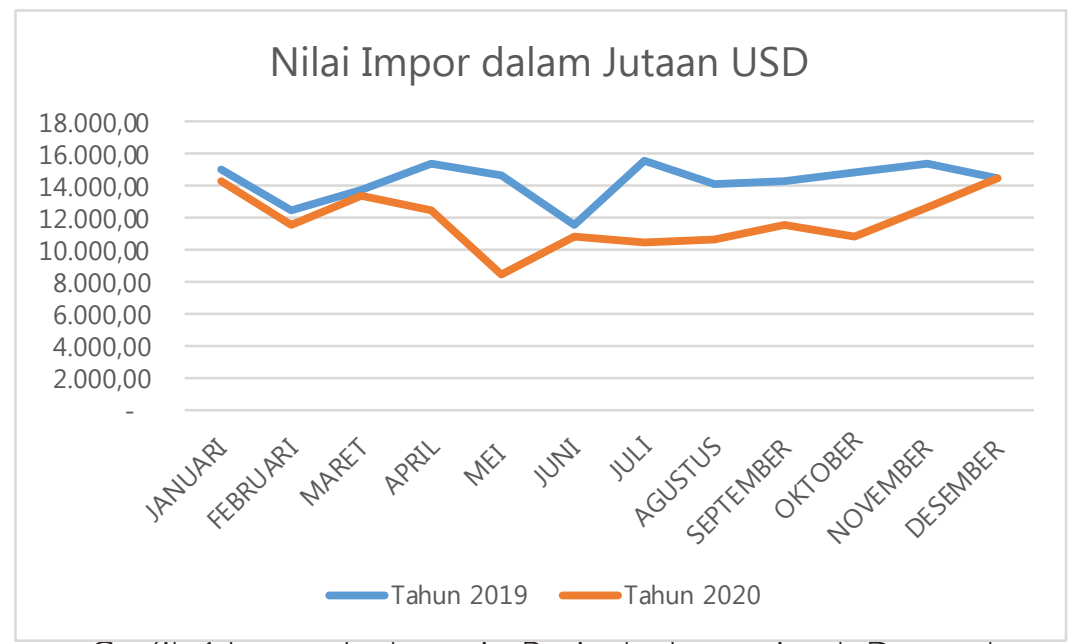

Gratik 1 Impor Indonesia Periode Januari s.d. Desember Sumber: Kementerian Perdagangan

Diketahui bahwa penurunan impor barang terbesar terjadi di bulan Mei 2020 dan total impor tahun 2020 mengalami penurunan dibandingkan 2019 yaitu sebesar 29.706,94 juta USD atau turun sebesar $17,34 \%$.

\subsubsection{Dampak Penerimaan PPN Impor}

Penerimaan perpajakan dari sektor PPN
Impor mengalami penurunan yang tajam setelah adanya insentif fiskal sesuai PMK No. 28/PMK.03/2020. Berikut tabel penerimaan PPN Impor masa Januari sampai dengan April 2020 sebelum berlakunya PMK dan masa Mei sampai dengan Desember setelah masa berlakunya PMK. 
Tabel 2 Penerimaan Bruto PPN Impor Periode Januari s.d. April Sumber: KPP Wajib Pajak Besar Dua

\begin{tabular}{|l|l|l|l|l|}
\hline Uraian & $\begin{array}{l}\text { Penerimaan Bruto } \\
\text { Januari s.d. April } \\
2019\end{array}$ & $\begin{array}{l}\text { Penerimaan Bruto } \\
\text { Januari s.d. April } \\
2020\end{array}$ & $\begin{array}{l}\text { Selisih } \\
\text { Naik / } \\
\text { (Turun) }\end{array}$ \\
\hline PPN Impor & 10.250 .050 .822 .304 & 9.429 .946 .597 .351 & (820.104.224.953) & (8\%) \\
\hline
\end{tabular}

Berdasarkan Tabel 2, diketahui bahwa penerimaan bruto PPN Impor periode Januari sampai dengan April 2020 mengalami penurunan dibandingkan periode yang sama tahun sebelumnya sebagai dampak berkurangnya aktivitas impor.

Tabel 3 Penerimaan Bruto PPN Impor Periode Mei s.d. Desember Sumber: KPP Wajib Pajak Besar Dua

\begin{tabular}{|l|l|l|l|l|}
\hline Uraian & $\begin{array}{l}\text { Penerimaan Bruto } \\
\text { Mei s.d. Desember } \\
2019\end{array}$ & $\begin{array}{l}\text { Penerimaan Bruto } \\
\text { Mei s.d. Desember } \\
2020\end{array}$ & Selisih & $\begin{array}{l}\text { Persentase } \\
\text { Naik / } \\
\text { (Turun) }\end{array}$ \\
\hline $\begin{array}{l}\text { PPN } \\
\text { Impor }\end{array}$ & 21.830 .682 .472 .185 & 15.864 .196 .242 .944 & $(5.966 .486 .229 .241)$ & (27.33\%) \\
\hline
\end{tabular}

Dari Tabel 3, diketahui bahwa penerimaan bruto PPN Impor mengalami kontraksi penurunan sebagai dampak berkurangnya aktivitas impor akibat perekonomian yang lesu dan berlakunya insentif fiskal berupa PPN impor tidak dipungut oleh pemerintah. Perusahaan yang melakukan impor atas raw material support mengurangi aktivitas importasi barang. Hal ini dikarenakan aktivitas industri manufaktur yang cenderung mengurangi proses produksi karena masih banyaknya stok barang jadi di gudang.

Berikut adalah grafik penurunan PPN Impor bulan Januari sampai dengan Desember 2020 dibandingkan dengan tahun sebelumnya.

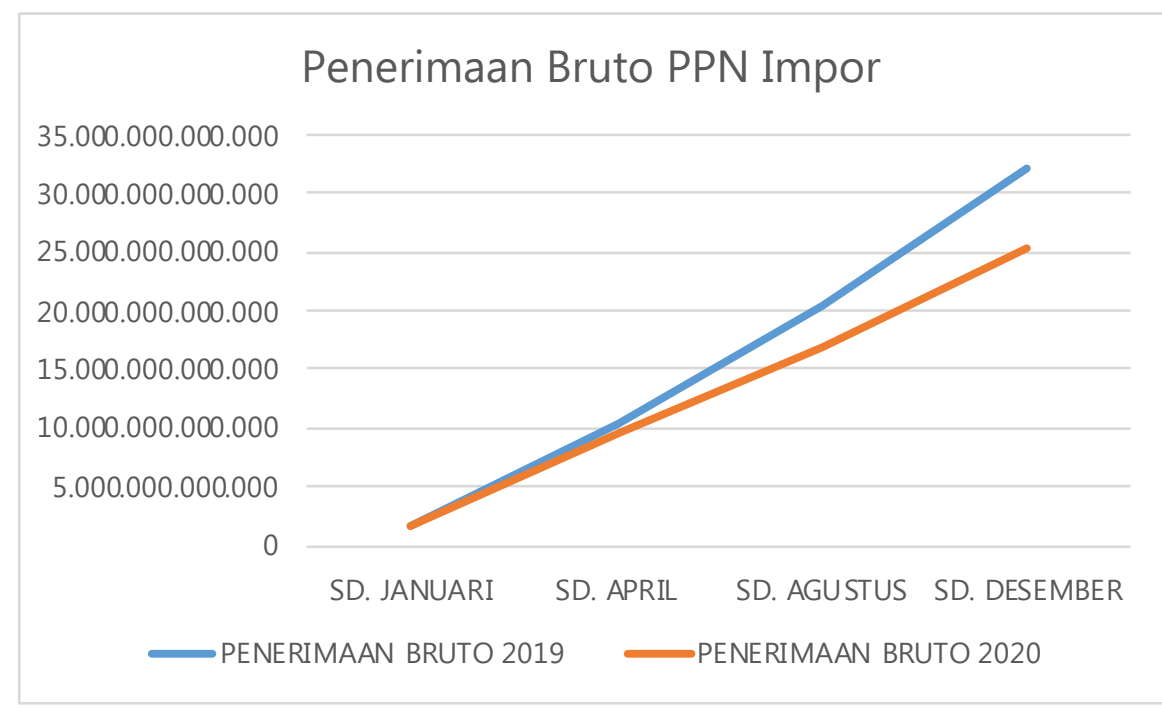

Grafik 2 Penerimaan Bruto PPN Impor Periode Januari s.d. Desember

Sumber: KPP Wajib Pajak Besar Dua 


\subsubsection{Dampak Penerimaan Pajak Penjualan atas Barang Mewah (PPnBM) Impor}

Berikut tabel penerimaan PPnBM Impor masa Januari sampai dengan April 2020, serta masa Mei sampai dengan Desember 2020.

Tabel 4 Penerimaan Bruto PPnBM Impor Periode Januari s.d. April Sumber: KPP Wajib Pajak Besar Dua

\begin{tabular}{|l|l|l|l|l|}
\hline Uraian & $\begin{array}{l}\text { Penerimaan } \\
\text { Bruto Januari s.d. } \\
\text { April 2019 }\end{array}$ & $\begin{array}{l}\text { Penerimaan } \\
\text { Bruto Januari s.d. } \\
\text { April 2020 }\end{array}$ & Selisih & $\begin{array}{l}\text { Persentase } \\
\text { Naik / } \\
\text { (Turun) }\end{array}$ \\
\hline PPnBM Impor & 660.984 .296 .000 & 940.962 .968 .000 & 279.978 .672 .000 & $42,3 \%$ \\
\hline
\end{tabular}

Berdasarkan Tabel 4, dapat diketahui bahwa penerimaan bruto PPnBM Impor periode bulan Januari sampai dengan bulan April 2020 mengalami kenaikan dibandingkan dengan periode yang sama pada tahun sebelumnya. Dengan demikian, masih terdapat banyak peminat atas produk barang mewah dan menandakan golongan orang kaya belum terlalu terdampak pandemi COVID-19 pada permulaan tahun 2020. PPnBM yang dikumpulkan di KPP Wajib Besar Dua sebagian besar diperoleh dari pungutan atas importir kendaraan roda dua dan roda empat atau lebih yang masuk pada kategori barang mewah.

Tabel 5 Penerimaan Bruto PPnBM Impor Periode Mei s.d. Desember Sumber: KPP Wajib Pajak Besar Dua

\begin{tabular}{|l|l|l|l|l|}
\hline Uraian & $\begin{array}{l}\text { Penerimaan Bruto } \\
\text { Mei s.d. Desember } \\
2019\end{array}$ & $\begin{array}{l}\text { Penerimaan Bruto } \\
\text { Mei s.d. Desember } \\
2020\end{array}$ & $\begin{array}{l}\text { Selisih } \\
\begin{array}{l}\text { Naik } \\
\text { (Turun) }\end{array}\end{array}$ \\
\hline $\begin{array}{l}\text { PPnBM } \\
\text { Impor }\end{array}$ & 2.065 .211 .727 .018 & 1.146 .805 .709 .000 & $(918.406 .018 .018)$ & $(44,4 \%)$ \\
\hline
\end{tabular}

Namun pada periode selanjutnya, penerimaan bruto PPnBM Impor mengalami kontraksi penurunan sebagai dampak berkurangnya aktivitas impor barang mewah karena lesunya penjualan kendaraan bermotor dalam negeri.

Berikut adalah grafik penurunan PPnBM Impor bulan Januari sampai dengan Desember 2020. 


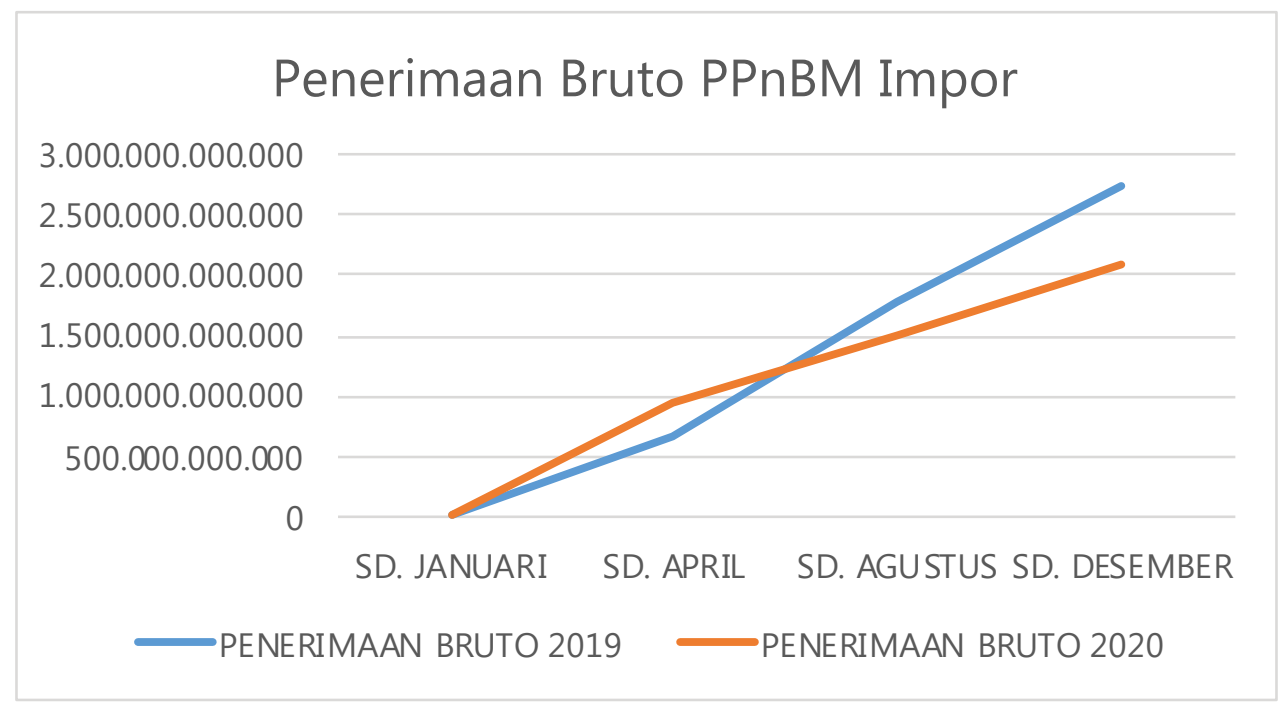

Grafik 3 Penerimaan Bruto PPnBM Impor Periode Januari s.d. Desember Sumber: KPP Wajib Pajak Besar Dua

\subsubsection{Dampak Penerimaan PPh Pasal 22 Impor}

Penerimaan perpajakan dari sektor PPh Pasal 22 Impor mengalami penurunan sejak berlakunya insentif fiskal sesuai PMK No. 28/PMK.03/2020. Berikut tabel penerimaan PPh Pasal 22 Impor masa Januari sampai dengan April 2020 sebelum berlakunya PMK. Serta masa Mei s.d. Desember setelah masa berlakunya PMK.

Grafik 3 Penerimaan Bruto PPnBM Impor Periode Januari s.d. Desember Sumber: KPP Wajib Pajak Besar Dua

\begin{tabular}{|l|l|l|l|l|}
\hline Uraian & $\begin{array}{l}\text { Penerimaan Bruto } \\
\text { Januari s.d. April } \\
2019\end{array}$ & $\begin{array}{l}\text { Penerimaan Bruto } \\
\text { Januari s.d. April } \\
2020\end{array}$ & $\begin{array}{l}\text { Selisih } \\
\text { Naik } \\
\text { (Turun) }\end{array}$ \\
\hline $\begin{array}{l}\text { PPh Pasal } \\
\text { 22 Impor }\end{array}$ & 3.143 .909 .978 .881 & $2,636,027,414,950$ & $(507.882 .563 .931)$ & $(16,1 \%)$ \\
\hline
\end{tabular}

Berdasarkan Tabel 6, diketahui bahwa penerimaan bruto PPh Pasal 22 Impor mengalami penurunan sebagai dampak berkurangnya aktivitas impor. Hal ini terjadi karena mulai lesunya perekonomian Indonesia selaku konsumen, sehingga eksportir produk kendaraan mewah baik dari Eropa, Amerika maupun Jepang mulai mengurangi persediaan kendaraannya.

Impor barang raw material berupa bahan baku obat dari Tiongkok, tidak termasuk barang mewah, sehingga tidak dikenakan PPh Pasal 22 Impor. Adapun impor 
Adapun impor alat-alat kesehatan dari Tiongkok belum mengalami peningkatan pada awal 2020

Tabel 7 Penerimaan Bruto PPh Pasal 22 Impor Periode Mei s.d. Desember Sumber: KPP Wajib Pajak Besar Dua

\begin{tabular}{|l|l|l|l|l|}
\hline Uraian & $\begin{array}{l}\text { Penerimaan Bruto } \\
\text { Mei s.d. Desember } \\
2019\end{array}$ & $\begin{array}{l}\text { Penerimaan } \\
\text { Bruto Mei s.d. } \\
\text { Desember 2020 }\end{array}$ & Selisih & $\begin{array}{l}\text { Persentase } \\
\text { Naik } \\
\text { (Turun) }\end{array}$ \\
\hline $\begin{array}{l}\text { PPh Pasal } \\
\text { 22 Impor }\end{array}$ & 6.705 .883 .670 .377 & 894.336 .916 .157 & $(5.811 .546 .754 .220)$ & (86,6\%) \\
\hline
\end{tabular}

Periode selanjutnya diketahui bahwa penerimaan bruto PPh Pasal 22 Impor mengalami kontraksi penurunan yang mendalam sebagai dampak berkurangnya aktivitas impor karena terdampak perekonomian yang lesu. Selain itu, penurunan juga dikarenakan adanya insentif fiskal berupa PPh Pasal 22 Impor tidak dipungut oleh pemerintah.

Berikut adalah grafik penurunan PPh Pasal 22 Impor bulan Januari sampai dengan Desember 2020 dibandingkan dengan tahun sebelumnya.

\section{Penerimaan Bruto PPh Pasal 22 Impor}

12.000 .000 .000 .000

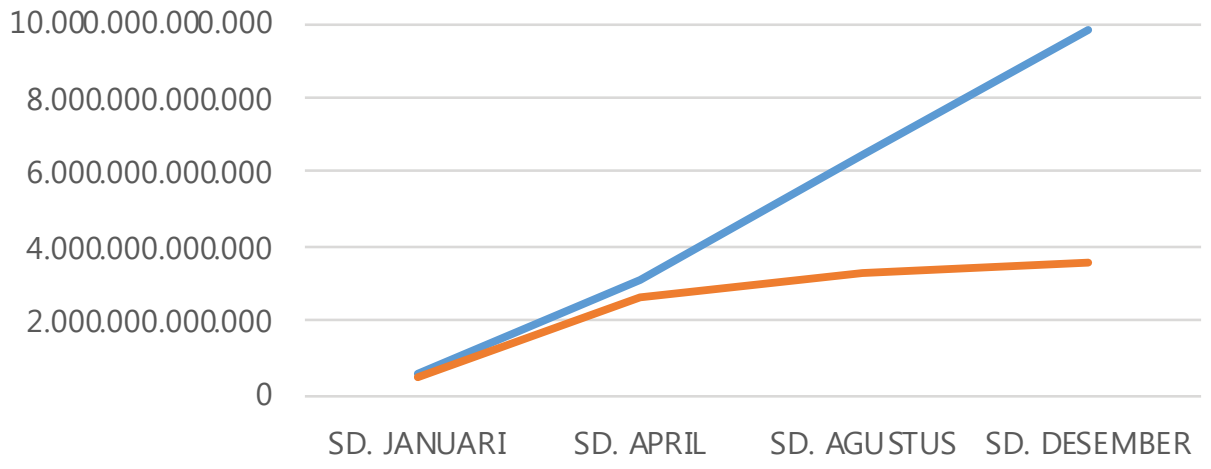

PENERIMAAN BRUTO 2019 PENERIMAAN BRUTO 2020

Grafik 4 Penerimaan Bruto PPh Pasal 22 Impor Periode Januari s.d. Desember Sumber: KPP Wajib Pajak Besar Dua

\subsection{Penurunan Transaksi Barang dan atau Jasa Dalam Negeri}

Dampak COVID-19 tidak hanya mengganggu sektor ekspor dan impor Indonesia, tetapi juga menyerang sektor perdagangan dalam negeri. Hal ini akan berdampak 
serius karena dalam penerimaan pajak sektor perdagangan memiliki kontribusi besar dalam penerimaan negara (Nasution et al., 2020). Perdagangan dalam negeri selain berpengaruh pada perputaran roda ekonomi, juga berdampak pada penerimaan PPN.

\subsubsection{Dampak Terhadap Penerimaan PPN Dalam Negeri}

Penerimaan perpajakan dari sektor PPN Dalam Negeri, selanjutnya disebut PPN DN, cenderung stabil. Berikut tabel penerimaan PPN DN masa Januari sampai dengan April 2020 sebelum berlakunya PMK serta masa Mei sampai dengan Desember setelah masa berlakunya PMK.

Tabel 8 Penerimaan Bruto PPN DN Periode Januari s.d. April

Sumber: KPP Wajib Pajak Besar Dua

\begin{tabular}{|l|lr|l|l|l|}
\hline Uraian & $\begin{array}{l}\text { Penerimaan Bruto } \\
\text { Januari s.d. April } \\
2019\end{array}$ & $\begin{array}{l}\text { Penerimaan Bruto } \\
\text { Januari s.d. April } \\
2020\end{array}$ & Selisih & $\begin{array}{l}\text { Persentase } \\
\text { Naik / } \\
\text { (Turun) }\end{array}$ \\
\hline $\begin{array}{l}\text { PPN } \\
\text { DN }\end{array}$ & 10.005 .044 .785 .864 & 12.359 .577 .603 .992 & 2.354 .532 .818 .428 & $23,5 \%$ \\
\hline
\end{tabular}

Dari Tabel 8 diketahui bahwa penerimaan bruto PPN DN naik karena aktivitas perdagangan dalam negeri yang belum terpengaruh pandemi. Penjualan kendaraan bermotor roda dua atau lebih, mempunyai peran besar dalam penerimaan PPN DN.

Tabel 9 Penerimaan Bruto PPN DN Periode Mei s.d. Desember

Sumber: KPP Wajib Pajak Besar Dua

\begin{tabular}{|l|l|l|l|l|}
\hline Uraian & $\begin{array}{l}\text { Penerimaan Bruto } \\
\text { Mei s.d. Desember } \\
2019\end{array}$ & $\begin{array}{l}\text { Penerimaan Bruto } \\
\text { Mei s.d. Desember } \\
2020\end{array}$ & $\begin{array}{l}\text { Selisih } \\
\text { Naik } \\
\text { (Turun) }\end{array}$ \\
\hline $\begin{array}{l}\text { PPN } \\
\text { DN }\end{array}$ & 23.136 .071 .363 .351 & 20.440 .532 .848 .055 & $(2.695 .538 .515 .296)$ & $(11,65 \%)$ \\
\hline
\end{tabular}

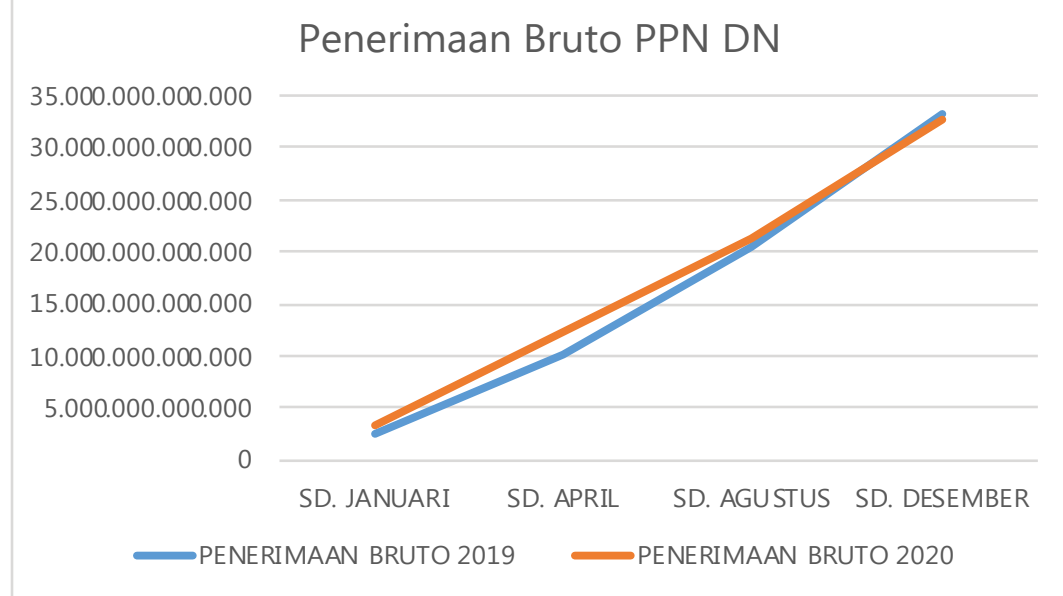

Grafik 5 Penerimaan Bruto PPN DN Periode Januari s.d. Desember

Sumber: KPP Wajib Pajak Besar Dua 
Dari Tabel 9 diketahui bahwa penerimaan bruto PPN DN mengalami penurunan sebagai dampak berkurangnya aktivitas perdagangan dalam negeri, serta ada beberapa penyerahan barang dan jasa yang ditanggung oleh Pemerintah Indonesia dalam rangka penanganan pandemi COVID-19.

Berikut adalah grafik penurunan PPN DN bulan Januari sampai dengan Desember 2020 dibandingkan dengan tahun sebelumnya.

Secara year on year, penerimaan bruto PPN DN tahun 2020 mengalami penurunan sebesar Rp. 342.112.863.266,- atau turun sebesar 1,03\% dibanding tahun 2019.

\subsubsection{Dampak Terhadap Penerimaan PPnBM Dalam Negeri}

Penerimaan perpajakan dari sektor PPnBM Dalam Negeri, selanjutnya disebut PPnBM DN, menurun seiring lesunya pendapatan orang kaya di Indonesia. Berikut ini merupakan tabel penerimaan PPnBM DN masa Januari sampai dengan April 2020 serta masa Mei sampai dengan September 2020.

Tabel 10 Penerimaan Bruto PPnBM DN Periode Januari s.d. April Sumber: KPP Wajib Pajak Besar Dua

\begin{tabular}{|l|l|l|l|l|}
\hline Uraian & $\begin{array}{l}\text { Penerimaan } \\
\text { Bruto Januari s.d. } \\
\text { April 2019 }\end{array}$ & $\begin{array}{l}\text { Penerimaan Bruto } \\
2020 \text { Januari s.d. } \\
\text { April }\end{array}$ & Selisih & $\begin{array}{l}\text { Persentase } \\
\text { Naik } \\
\text { (Turun) }\end{array}$ \\
\hline PPnBM DN & 1.656 .772 .650126 & 2.339 .254 .338 .058 & 682.481 .687 .932 & $41,19 \%$ \\
\hline
\end{tabular}

Dari Tabel 10, diketahui bahwa penerimaan bruto PPnBM DN mengalami kenaikan karena wajib pajak yang kaya belum terdampak pandemi COVID-19 masih membelanjakan dananya untuk membeli barang kategori mewah. Penjualan terbesar masih didominasi kendaraan, dan industri otomotif masih memainkan peran penting dalam memutar roda perekonomian pada awal 2020.

Tabel 11 Penerimaan Bruto PPnBM DN Periode Mei s.d. Desember Sumber: KPP Wajib Pajak Besar Dua

\begin{tabular}{|l|l|l|l|l|}
\hline Uraian & $\begin{array}{l}\text { Penerimaan Bruto } \\
\text { Mei s.d. Desember } \\
2019\end{array}$ & $\begin{array}{l}\text { Penerimaan Bruto } \\
\text { Mei s.d. Desember } \\
2020\end{array}$ & $\begin{array}{l}\text { Selisih } \\
\text { Persentase } \\
\text { Naik / } \\
\text { (Turun) }\end{array}$ \\
\hline $\begin{array}{l}\text { PPnBM } \\
\text { DN }\end{array}$ & 5.934 .549 .542 .344 & 1.947 .920 .613 .537 & $(3.986 .628 .928 .807)$ & $(67,1 \%)$ \\
\hline
\end{tabular}

Dari Tabel 11, diketahui bahwa penerimaan bruto PPnBM DN mengalami penurunan sebagai dampak berkurangnya aktivitas perdagangan barang mewah di dalam negeri. 


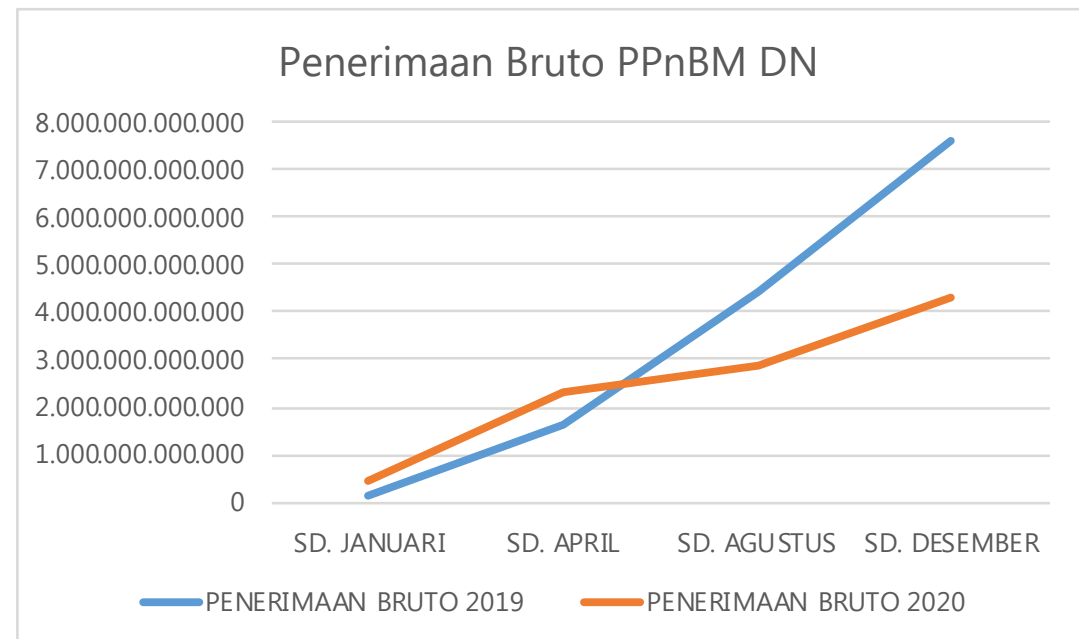

Grafik 6 Penerimaan Bruto PPnBM DN Periode Januari s.d. Desember Sumber: KPP Wajib Pajak Besar Dua

\subsection{Dampak Insentif Fiskal PMK No. 23/PMK.03/2020 Terhadap PPh Pasal 21}

Dalam PMK No. 23/PMK.03/2020 tanggal 21 Maret 2020 yang mulai berlaku tanggal 01 April 2020, terdapat insentif berupa PPh Pasal 21 ditanggung Pemerintah (DTP) bagi karyawan yang bekerja di Klasifikasi Lapangan Usaha (KLU) tertentu, yang menerima atau memperoleh penghasilan bruto yang bersifat tetap dan teratur yang disetahunkan tidak lebih dari Rp 200.000.000,-

Adapun wajib pajak yang terdaftar di KPP Wajib Pajak Besar Dua yang memanfaatkan beberapa insentif fiskal adalah sebagai berikut.

Tabel 12 Rekapitulasi Permohonan Insentif Fiskal

Sumber: KPP Wajib Pajak Besar Dua

\begin{tabular}{|l|l|c|c|}
\hline \multirow{2}{*}{ No } & \multicolumn{1}{|c|}{ Uraian Jenis Pajak } & \multicolumn{2}{|c|}{ Permohonan } \\
\cline { 3 - 4 } & & Masuk & Disetujui \\
\hline 1 & PPh Pasal 21 & 344 & 339 \\
\hline 2 & PPh Pasal 22 Impor & 194 & 182 \\
\hline 3 & PPh Pasal 22 Dalam Negeri & 205 & 205 \\
\hline 4 & PPh Pasal 23 & 2 & 2 \\
\hline 5 & PPh Pasal 25 & 175 & 166 \\
\hline 6 & PPh Final & 3 & 3 \\
\hline & Total & 923 & 897 \\
\hline
\end{tabular}

Berdasarkan wajib pajak pusat sejumlah 250 perusahaan dan wajib pajak cabang yang terdaftar di KPP Wajib Pajak Besar Dua sejumlah 255 perusahaan, wajib pajak yang mengajukan insentif fiskal terbanyak berupa insentif atas PPh Pasal 21. Adapun total permohonan yang disetujui adalah 897 permohonan. 


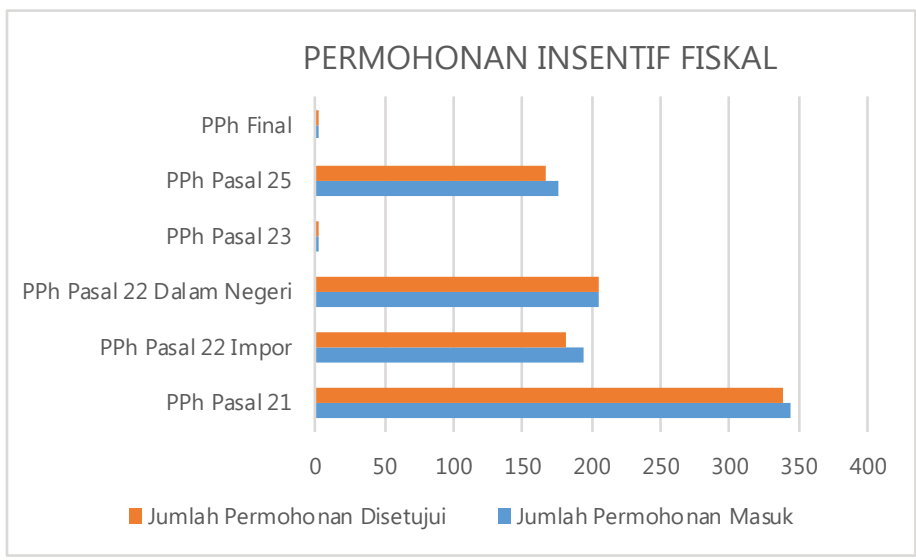

Grafik 7 Permohonan Insentif Fiskal

Sumber: KPP Wajib Pajak Besar Dua

Permohonan yang diterima untuk mendapatkan insentif fiskal terbanyak berupa PPh Pasal 21 yang dimaksudkan dapat memberikan dampak yang signifikan bagi perekonomian. Hal ini dikarenakan melalui insentif atas PPh Pasal 21, karyawan mendapatkan pertambahan kemampuan ekonomis yang dapat dibelanjakan untuk memutar roda perekonomian.

Penerimaan perpajakan masa Januari sampai dengan Desember 2020 dari sektor PPh Pasal 21 menurun dibandingkan dengan periode sebelumnya sebagaimana dapat dilihat pada Tabel 13 karena adanya insentif fiskal.

Tabel 13 Penerimaan Bruto PPh Pasal 21 Periode Januari s.d. Desember Sumber: KPP Wajib Pajak Besar Dua

\begin{tabular}{|l|l|l|l|l|}
\hline Uraian & $\begin{array}{l}\text { Penerimaan Bruto } \\
\text { Januari s.d. } \\
\text { Desember 2019 }\end{array}$ & $\begin{array}{l}\text { Penerimaan Bruto } \\
\text { Januari Seld. } \\
\text { Desember 2020 }\end{array}$ & Selisih & $\begin{array}{l}\text { Persentase } \\
\text { Naik / } \\
\text { (Turun) }\end{array}$ \\
\hline $\begin{array}{l}\text { PPh Pasal } \\
21\end{array}$ & 6.293 .020 .103 .293 & 5.863 .656 .004 .199 & $(429.364 .099 .094)$ & $(6,82 \%)$ \\
\hline
\end{tabular}

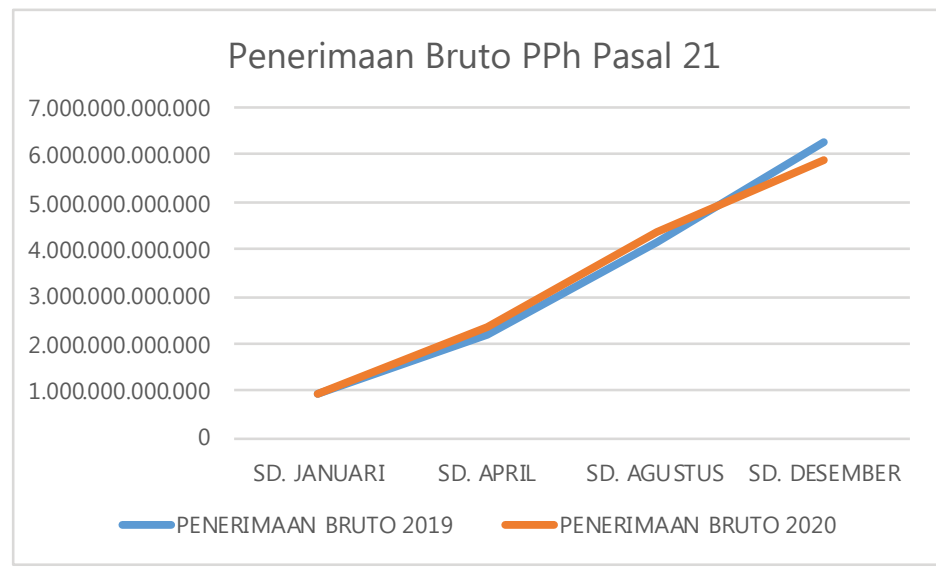

Grafik 8 Penerimaan Bruto PPh Pasal 21 Periode Januari s.d. Desember

Sumber: KPP Wajib Pajak Besar Dua 
Penurunan penerimaan PPh Pasal 21 selain dikarenakan adanya insentif fiskal, juga dikarenakan berkurangnya pemberian bonus kepada karyawan selama tahun 2020.

Pemberian insentif fiskal berupa PPh pasal 21 DTP perlu diperluas lebih lanjut karena selain hanya berpengaruh sedikit terhadap penerimaan pajak, juga disebabkan karena dampaknya yang berpengaruh langsung terhadap perputaran perekonomian. Hal-hal yang dapat diperluas kriterianya antara lain:

a. Batasan pegawai yang dapat menikmati insentif berupa penghasilan bruto disetahunkan, yang semula dari Rp. 200.000.000,dinaikkan menjadi misalnya Rp. 300.000.000,--.

b. Perluasan Klasifikasi Lapangan Usaha $(K L U)$, sehingga lebih banyak bidang usaha yang dapat menikmati insentif tersebut.

c. Perpanjangan masa manfaat atas
PPh pasal 21 DTP, misalnya sampai dengan akhir tahun 2021.

\subsection{Dampak Seluruh Insentif Fiskal Terhadap Kinerja Penerimaan}

Secara keseluruhan penerimaan perpajakan di KPP Wajib Pajak Besar mengalami penurunan karena adanya insentif fiskal sebagaimana tergambar pada penerimaan pajak di tahun 2020 dibandingkan dengan periode sebelumnya. Selain itu penurunan penerimaan terjadi karena lesunya perdagangan baik dalam negeri maupun perdagangan internasional selama pandemi COVID-19, dalam artian terjadi stagnasi dalam roda perekonomian.

Tabel 14 merupakan perbandingan penerimaan bruto atas wajib pajak yang mendapatkan insentif fiskal dan yang selain penerima insentif fiskal untuk tahun 2020 dibanding 2019 di KPP Wajib Pajak Besar Dua

Tabel 14 Penerimaan Bruto KPP Wajib Pajak Besar Dua Sumber: KPP Wajib Pajak Besar Dua

\begin{tabular}{|l|r|r|r|}
\hline \multicolumn{1}{|c|}{ Uraian } & $\begin{array}{l}\text { Penerimaan Bruto } \\
\text { Januari s.d. Desember } \\
2019\end{array}$ & $\begin{array}{l}\text { Penerimaan Bruto } \\
\text { Januari s.d. Desember } \\
2020\end{array}$ & $\begin{array}{l}\text { Selisih Untuk Periode } \\
\text { Yang Sama }\end{array}$ \\
\hline $\begin{array}{l}\text { WP Penerima } \\
\text { Insentif Fiskal }\end{array}$ & 117.024 .511 .129 .431 & 88.759 .042 .444 .238 & $(28.265 .468 .685 .193)$ \\
\hline $\begin{array}{l}\text { WP Selain } \\
\text { Penerima Insentif } \\
\text { Fiskal }\end{array}$ & 24.490 .305 .266 .404 & 22.068 .454 .226 .031 & $(2.421 .851 .040 .373)$ \\
\hline \multicolumn{1}{|c|}{ Total } & 141.514 .816 .395 .835 & 110.827 .496 .670 .269 & $(30.687 .319 .725 .566)$ \\
\hline
\end{tabular}

Dari Tabel 14, wajib pajak yang mendapatkan insentif fiskal merupakan penyumbang terbesar bagi penerimaan kantor yaitu sebesar $82,6 \%$ pada tahun
2019. Hal ini akan berdampak signifikan jika terdapat kontraksi ekonomi dan pemberian insentif fiskal secara berkesinambungan. 
Grafik berikut menggambarkan kinerja penerimaan secara bruto di KPP Wajib Pajak Besar Dua sebelum dan sesudah adanya insentif fiskal sehubungan dengan pemulihan ekonomi nasional sebagai dampak pandemi COVID-19.

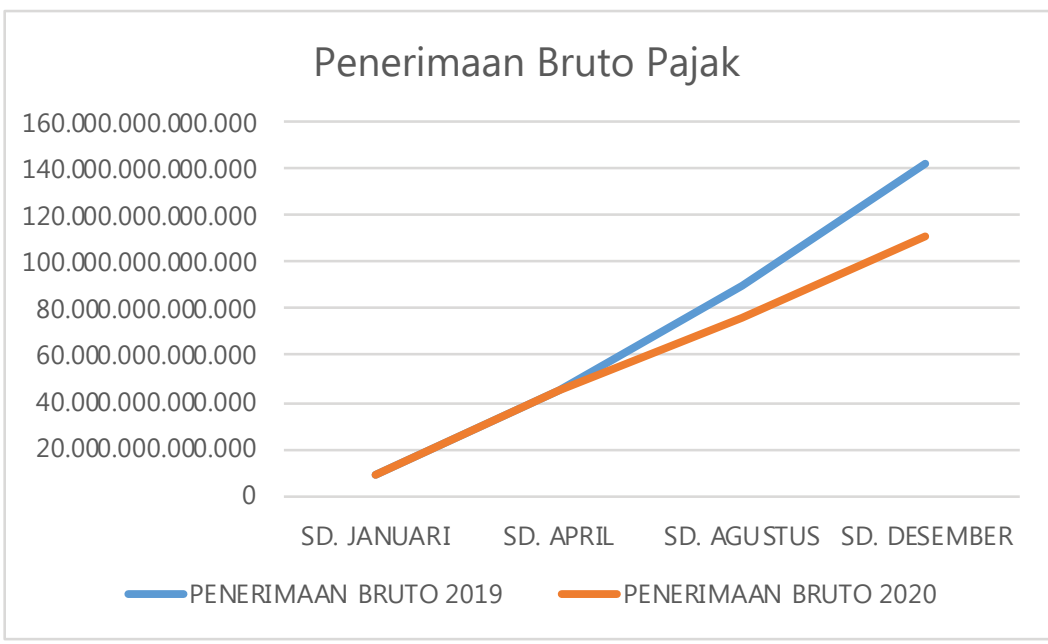

Grafik 9 Penerimaan Bruto KPP Wajib Pajak Besar Dua

Periode Januari s.d. Desember 2019 dan 2020

Sumber: KPP Wajib Pajak Besar Dua

Grafik di atas menyatakan bahwa penerimaan pajak pada Januari sampai dengan April 2020 masih meningkat, namun mulai bulan Mei 2020 penerimaan pajak mengalami penurunan dibanding periode yang sama di tahun 2019.

\subsection{Perihal Insentif Fiskal Penghapusan PPnBM atas Penjualan Mobil Baru}

Pemerintah memberikan relaksasi keringanan PPnBM untuk kendaraan bermotor tertentu dengan menerbitkan Peraturan Menteri Keuangan Nomor 20/PMK.010/2021. Adanya kebijakan ini diharapkan bisa mendorong penjualan yang terdampak pandemi COVID-19.

Pemberian insentif akan terbagi ke dalam tiga tahap. Adapun besaran insentif yang diberikan mencapai 100 persen pada tahap pertama (Masa
Pajak Maret sampai dengan Mei 2021), 50 persen pada tahap kedua (Masa Pajak Juni sampai dengan Agustus 2021), dan 25 persen di tahap ketiga (Masa Pajak September sampai dengan Desember 2021).

Industri otomotif merupakan industri yang padat modal dan padat karya, dalam artian mampu menyerap tenaga kerja dalam jumlah yang banyak. Dengan adanya insentif PPnBM DN, pelaku industri berharap dapat berkontribusi dalam mendorong percepatan perekonomian masyarakat melalui peningkatan permintaan masyarakat karena harga mobil baru yang lebih murah. Diharapkan dengan penjualan yang semakin meningkat, industri otomotif dapat menghindarkan diri dari Pemutusan Hubungan Kerja (PHK) kepada karyawan yang bergerak di bidang otomotif tersebut, baik industri 
manufaktur maupun distributor otomotif.

Namun demikian, penulis tidak sependapat dengan usulan tersebut karena karakteristik mobil bukanlah suatu kebutuhan pokok yang perlu diberikan tarif PPnBM 0\%. Mobil dalam masa pandemi COVID-19 masih dianggap sebagai barang mewah untuk masyarakat kelas menengah ke bawah. Sedangkan, terdapat banyak masyarakat yang menganggur dan tidak menerima penghasilan sebagai akibat dari PHK. Selain itu penerimaan pajak dari PPnBM atas penjualan mobil baru akan semakin memperberat penerimaan pajak tahun berjalan sehingga ketahanan fiskal akan semakin rapuh.

\section{KESIMPULAN}

Pandemi COVID-19 telah memberikan dampak negatif berupa penurunan penerimaan pajak di KPP Wajib Pajak Besar Dua. Pemberian insentif fiskal berupa PPh pasal 21 yang DTP perlu diperluas kriterianya karena dampaknya yang berpengaruh langsung terhadap perputaran perekonomian. Selain itu, permintaan insentif fiskal berupa pengenaan tarif PPnBM sebesar 0\% atas industri otomotif sebaiknya tidak dilakukan perpanjangan untuk tahun berikutnya karena akan memperlemah ketahanan fiskal.

\section{IMPLIKASI DAN KETERBATASAN}

Kebijakan fiskal yang diambil dalam menanggulangi dampak COVID-19 perlu dikaji lebih mendalam agar dapat dirasakan masyarakat. Pemulihan ekonomi nasional hendaknya dilakukan dengan tetap melihat implikasinya terhadap penerimaan pajak. Hasil penelitian menunjukkan insentif fiskal mengakibatkan penurunan penerimaan pajak, namun bagi wajib pajak tertentu terutama karyawan akan menambah kemampuan ekonomis.

Penelitian telah diusahakan dan dilaksanakan sesuai dengan prosedur ilmiah, namun belum mewakili penerimaan secara nasional dikarenakan objek penelitian hanya penerimaan pajak di satu KPP.

\section{DAFTAR PUSTAKA}

[1] Carpendale, S., Knudsen, S., Thudt, A., \& Hinrichs, U. (2017). Analyzing qualitative data. Proceedings of the 2017 ACM International Conference on Interactive Surfaces and Spaces, 477-481. https://doi.org/10.1145/3132272.3135087

[2] CNBC Indonesia TV. (2020). OECD prediksi pertumbuhan ekonomi global -4,2\% pada 2020. CNBC Indonesia. https://www.cnbcindonesia.com/news/202012 02182305-8-206421/oecd-prediksi-pertumbu han-ekonomi-global-42-pada-2020

[3] Darussalam. (2020). Peran pajak sebagai penyelamat dampak COVID-19. DDTC News. https://news.ddtc.co.id/peran-pajak-sebagai-p enyelamat-dampak-COVID-19-24258?page_y $=1400$

[4] Feranika, A., \& Haryati, D. (2020). Strategi kebijakan fiskal terhadap output dan inflasi pada perekonomian indonesia dalam menghadapi dampak virus COVID 19. Business Innovation and Entrepreneurship Journal, 2(3), 146-152. https://doi.org/10.35899/biej.v2i3.154

[5] Friana, H. (2020, April 1). COVID-19 tekan perekonomian, pendapatan negara diprediksi turun 10\%. Tirto.ld. https://tirto.id/COVID-19 -tekan-perekonomian-pendapatan-negara-di prediksi-turun-10-eKdb

[6] Kementerian Perdagangan. (2021). Perkembangan impor nonmigas (negara asal). 
Portal Statistik Perdagangan. https://statistik. kemendag.go.id/growth-of-non-oil-and-ga s-import-origins-country

[7] Komite Penanganan COVID-19 Dan Pemulihan Ekonomi Nasional. (n.d.). No title. Retrieved April 10, 2021, from https://COVID19.go.id

[8] McNabb, D. E. (2017). How to write a research proposal. In Research Methods in Public Administration and Nonprofit Management (pp. 100-108). Routledge. https://doi.org/10.4324/9781315181158-9

[9] Minakshi. (2017). Applications of mathematics in various economic fields. Research Journal of Science and Technology, 9(1), $\quad$ 175. $\quad$ https://doi.org/10.5958/ 2349-2988.2017.00029.8

[10] Moen, K., \& Middelthon, A.-L. (2015). Qualitative research methods. In Research in Medical and Biological Sciences (pp. 321-378). Elsevier. https://doi.org/10.1016/ B978-0-12-799943-2.00010-0

[11] Nasution, D. A. D., Erlina, E., \& Muda, I. (2020). Dampak pandemi COVID-19 terhadap perekonomian Indonesia. Jurnal Benefita, 5(2), 212. https://doi.org/ 10.22216/jbe.v5i2.5313

[12] Pink, B. (2021). BPS catat pertumbuhan ekonomi sepanjang tahun 2020 minus 2,07\%. Kontan.Co.ld. https://nasional. kontan.co.id/news/bps-catat-pertumbuhan -ekonomi-sepanjang-tahun-2020-minus207

[13] Saptati, R. (2020). Menyelamatkan manusia dari pandemi. Kementerian Keuangan, 12-14. https://www.kemenkeu.go.id/ media/15239/media-keuangan-edisi-juni-2 020-rev.pdf

[14] Sugiyono. (2013). Metode penelitian kuantitatif, kualitatif dan R\&D. Bandung: Alfabeta.

[15] Webinar Efektifitas Kebijakan Moneter Masa Pandemi COVID-19 di Indonesia. (2020). InterCAFE. https://intercafe.ipb.ac.id/ efektifitas-kebijakan-moneter-masa-pande mi-COVID-19-di-indonesia/

[16] World Health Organization. (2020). WHO coronavirus (COVID-19) dashboard. World Health Organization. https://COVID19. who.int/ 